\title{
Modeling the Production of Natural Gas Hydrates in Laboratory Conditions
}

\author{
Ján Siažik ${ }^{1, *}$, Milan Malcho ${ }^{1}$, and Stanislav Gavlas ${ }^{1}$ \\ ${ }^{1}$ Department of Power Engineering, Univerzitná 1, 01026 Žilina, Slovakia
}

\begin{abstract}
Natural gas hydrates are in nature sources of primary energy. They are possible to created in laboratory conditions also under certain temperature and pressure conditions. With determining whether founding suitable conditions is closely linked to the creation of a physical model. The article deals with the model of natural gas hydrates.
\end{abstract}

\section{Introduction}

Energy storage is nowadays an interesting phenomenon that tends to move forward. There are many options to store energy, for example water energy - construction of dams and pumping tanks or capture of tidal wave energy. Also solar energy and its conversion to electrical energy and storage in accumulators, etc. natural gas or methane reserves are stored in the form of hydrates in nature. The hydrate can be produced also under laboratory conditions. Accumulation of energy into the form of hydrate is of great importance in terms of storage capacity, safety, transport to the place of consumption and coverage of unexpected energy peaks in the technology industry. The hydrate is generally a substance comprising water and hydrocarbons (or other gases). The storage of natural gas in hydrates (especially methane) is particularly advantageous in terms of storage capacity but also in terms of gas storage safety, which is possible at higher temperatures and lower pressures compared to other storage technologies. The natural gas hydrate is in a solid state, which accounts for about $85 \%$ of water and $15 \%$ of the gas bound in the clathrate lattice. Hydrates also have some uncertainty about ongoing research and their use as potential sources of income. The gas hydrate can be a great source of energy that begins to be considered for natural gas supplies for the coming decades. It is estimated that $99 \%$ of the global stock of gas hydrates is present in marine sediments under the corresponding temperature and pressure conditions prevailing in the top ten to hundreds of meters of seabed, in sediments at depths of $300 \mathrm{~m}$ and up to $4000 \mathrm{~m}$. Hydrates also occur on continent, but only in areas of permafrost ie in long-term freezing areas with temperature all year below $0{ }^{\circ} \mathrm{C}$. Storing energy in a convenient form for safe storage and its subsequent release is a current challenge in processes that use the need for energy to accumulate. The use of methane hydrates in practice could be for example, ensuring peak coverage in cogeneration electricity and heat generation by natural gas released from hydrates [1-4]. In Figure 1 is a burning gas hydrate sample.

\footnotetext{
*Corresponding author: jan.siazik@,fstroj.uniza.sk
} 


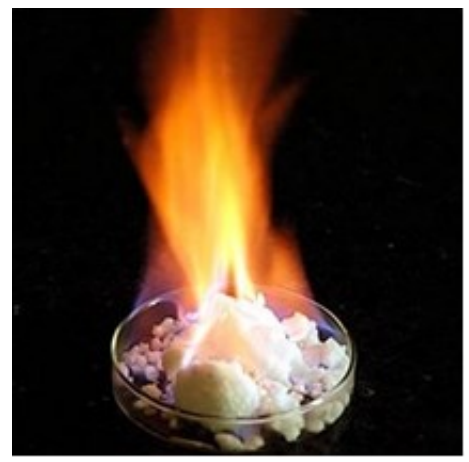

Fig. 1. Burning sample of gas hydrate.

\section{Modelling hydrate creation}

This part of article describe a part of chosen parameters necessary to determination model of hydrate creation. Injection capacity $Q_{D}\left[\mathrm{~m}^{3} \cdot \mathrm{s}^{-1}\right]$ is one of the important parameters. It is calculated according to the following relationship [5]:

$$
Q_{D}=5.4 \cdot 10^{-6} \cdot\left(\rho_{w} \cdot d_{0}^{3} \cdot \frac{v_{0}^{3}}{\sigma}\right) \cdot\left(\frac{l_{0}}{d_{0}}\right)^{0.75} \cdot(\sin \alpha)^{-0.2}
$$

Where $\rho_{W}$ - density of liquid $\left[\mathrm{kg} . \mathrm{m}^{-3}\right], d_{0}$ - diameter of nozzle $\left[4.1 .10^{-4} \mathrm{~m}\right], v_{0}$ - average velocity of liquid at outlet was calculated as $16.8\left[\mathrm{~m}_{\mathrm{s}} \mathrm{s}^{-1}\right], \sigma-$ surface tension of water [0.065 N.m $\left.\mathrm{m}^{-1}\right], l_{0}-$ lenght of nozzle $[0.05 \mathrm{~m}], \alpha$ - nozzle spray angle [0.96 rad].

As example was used volume flow rate of nozzle size 0.4 which at pressure 70 bar is $7.61 . \mathrm{h}^{-1}$.

Velocity $v_{0}$ was calculated as ratio volume flow rate of nozzle $\left[\mathrm{m}^{3} \cdot \mathrm{s}^{-1}\right]$, and nozzle crosssectional area $S\left[\mathrm{~m}^{2}\right]$. Injection capacity in our case is $8.96 .10^{-7} \mathrm{~m}^{3} \cdot \mathrm{s}^{-1}$.

Next parameter is Sauter mean diameter, calculated as follows [5]:

$$
S M D=4.4 S T^{0.6} \mu_{L}^{0.16} \rho_{L}^{-0.16} Q_{L}^{0.22} \Delta P_{L}^{-0.43}
$$

Where $S T$ - surface tension $\left[\mathrm{kg} \cdot \mathrm{s}^{-2}\right], Q_{L}$ - volume flow rate of liquid $\left[\mathrm{m}^{3} . \mathrm{s}^{-1}\right], \Delta p_{L}$ - fluid pressure $[\mathrm{Pa}], \mu_{L}-$ dynamic viscosity $\left[\mathrm{kg} \cdot \mathrm{m}^{-1} \cdot \mathrm{s}^{-1}\right]$. Sauter mean diameter is in our case $1.6 .10^{-5} \mathrm{~m}$.

For the gas-water transmission properties have a fluence diffusion coefficient. The diffusion coefficient $\left[\mathrm{cm}^{2} . \mathrm{s}^{-1}\right]$ of the gaseous components in water was calculated as follows for the hydrate-forming components using the Wilke-Chang correlation [5]:

$$
D c=\frac{7,4 \times 10^{-8}\left(\varepsilon \cdot M W_{W}\right)^{0,5} T}{\mu_{w} \cdot V_{m}^{0,6}}
$$

Where $\varepsilon$-is an asociation factor of solvent (for water $\varepsilon=2.26$ ), $M W_{w}-$ molecular weight of water $\left[\mathrm{g} \cdot \mathrm{mol}^{-1}\right], \mu_{w}-$ dynamic viscosity $\left[\mathrm{kg} \cdot \mathrm{m}^{-1} \cdot \mathrm{s}^{-1}\right], V m-$ molar volume of gas $\left[\mathrm{dm}^{3} \cdot \mathrm{mol}^{-1}\right]$.

Also for transfer properties of the gaseous mass in the water during spraying influence the transfer properties. The weight transfer coefficient of gaseous components in water droplets was calculated on the assumption that the droplets from the spray nozzle were well mixed [6]. A model designed by Srinivasan and Aiken [7] based on Levich Theory [8] and 
was used to determine the weight transfer factors of water components in water. The weight transfer factor is as follows [5]:

$$
K_{l}=\frac{0.16 D_{c}}{d_{p}} S c^{0.5} W e^{0.5} R e^{5 / 16}
$$

Where $D c$ - diffusion coefficient, $d p$ - charakteristic dimension of dropplet [m], $\sigma$ - surface tension $\left[\mathrm{J} . \mathrm{m}^{-2}\right], \rho_{w}$ - water density $\left[\mathrm{kg} . \mathrm{m}^{-3}\right], v_{p}$ - flow rate of the particles $\left[\mathrm{m} . \mathrm{s}^{-1}\right]$, $S c$ - Schmidt number, $W e-$ Weber number, $R e-$ Reynolds number.

$$
\begin{aligned}
& S_{c}=\frac{\mu_{w}}{\rho_{w} \cdot D_{c}} \\
& W_{e}=\frac{v_{p}^{2} \rho_{w} d_{p}}{\sigma} \\
& R_{e}=\frac{d_{p} v_{p} \rho_{w}}{\mu_{w}}
\end{aligned}
$$

The average weight transfer coefficient was obtained for the gas by normalizing the individual mass transfer coefficients of hydrate-forming components based on the composition of the gas-forming gas hydrate in the natural gas mixture. The initial particle velocity $v_{0}\left[\mathrm{~m} . \mathrm{s}^{-1}\right]$ emerging from the nozzle is given by the value [9], where $\varphi$ is the nozzle geometry taken as $=1[5]$.

$$
v_{0}=\varphi \sqrt{\frac{2 \cdot \Delta \cdot p_{n}}{\rho_{p}}}
$$
[10]:

The resistance coefficient is calculated from the following correlation as described in

$$
c_{d}=\left(\frac{24}{R_{e p}}\right) \cdot\left(1+0.14 \cdot R_{e p}^{0.7}\right) ; 0.1<R_{e p}<1000
$$

Where $\mathrm{R}_{\mathrm{ep}}$ is Reynolds number of particles given by relation [5]:

$$
R_{e p}=\frac{S M D \cdot v_{0} \rho}{\mu}
$$

It is also possible to calculate the feed rate in reactor $r$, provided that the sprayed particles were evenly deposited on the bottom of the vessel [5]. Where $\rho_{h}^{b}$ is volume density of the hydrate $\left[\mathrm{kg} . \mathrm{m}^{-3}\right]$ and $D_{v}$ is the inside diameter of the container [m] taken as $0.18 \mathrm{~m}$.

$$
r=\frac{Q \cdot \rho_{w}}{\rho_{h}^{b} \cdot \pi \cdot\left(D_{v} / 2\right)^{2}}
$$

Concentration of gas at the gas-liquid interface under pressure $C s o l\left[\right.$ mole. $\left.\mathrm{m}^{-3}\right]$ :

$$
C_{\text {sol }}=X \cdot \frac{\rho}{M}
$$

Where $X$ - molar solubility of gas in water $X(p, T) ; p=1.10^{7} \mathrm{~Pa}, T=275.15 \mathrm{~K}$ $\rho$ - water density $\left[\mathrm{kg} \cdot \mathrm{m}^{-3}\right], M-$ mole mass water $\left[\mathrm{kg} \cdot \mathrm{mol}^{-1}\right], M=0.018 \mathrm{~kg} \cdot \mathrm{mol}^{-1}$. In our case, the concentration is 1388 mol. $\mathrm{m}^{-3}$.

The gas constant is equal to $R=8314 \mathrm{~J} \cdot \mathrm{kmol}^{-1} \cdot \mathrm{K}^{-1}$ and the gas concentration in the fluid $c_{b}\left[\mathrm{~mol} . \mathrm{m}^{-3}\right]$ at the hydration pressure and equilibrium temperature is calculated as [5]:

$$
C_{b}=\frac{p}{R . T} .1000
$$


The ratio of gas dissolution in $r_{l}\left[\mathrm{~mol} . \mathrm{s}^{-1}\right]$ is calculated as follows:

$$
r_{1}=k_{l} \cdot A_{g} \cdot\left(c_{s o l}-c_{b}\right)
$$

Where: $k_{l}$ - diffusion coefficient of gas in water $\left[\mathrm{m} \cdot \mathrm{s}^{-1}\right], D$ - methane coefficient in water at barometric pressure and temperature $25{ }^{\circ} \mathrm{C}=0.0000149\left[\mathrm{~cm}^{2} \cdot \mathrm{s}^{-1}\right], \mathrm{Ag}$ - surface area of bubbles $\left[\mathrm{m}^{2}\right]$. In our case, its value is $1.41 .10^{-14}$.

Hydrate formation in the water spray system in the gas environment would be subject to the process of heterogeneous nucleation, which occurs at the gas-solution interface. Areas of n-shaped units of hydrated lens are shown in Figure 2 together with "humidification angles" ( $\theta$ and $\theta_{0}$ equation 15,16 ) with respect to each phase where $\sigma$ is the specific surface energy of the interface solution-hydrate, $\sigma_{s g}$ is the specific surface energy of the interface-solutiongas, $\sigma_{h g}$ is the specific surface energy of the hydrate-gas. In the case of lens-type clusters, the "humidification angles" are shown in $[5,11]$ as follows:

$$
\begin{aligned}
& \cos \theta=\frac{\left(\sigma_{s g}^{2}+\sigma^{2}-\sigma_{h g}^{2}\right)}{2 \sigma_{s g} \sigma} \\
& \cos \theta_{0}=\frac{\left(\sigma_{s g}^{2}-\sigma^{2}+\sigma_{h g}^{2}\right)}{2 \sigma_{s g} \sigma_{h g}}
\end{aligned}
$$

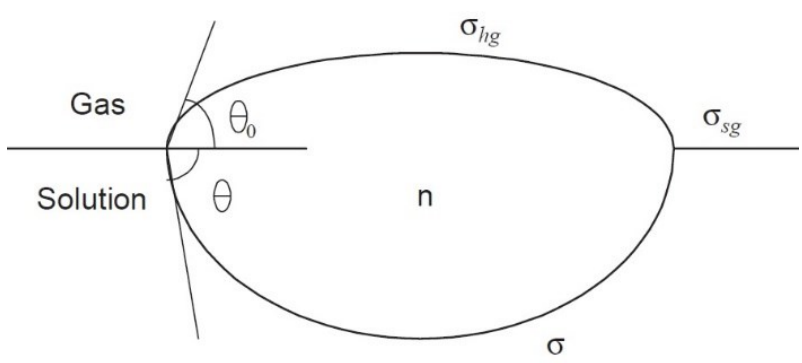

Fig. 2. Schematic diagram $n$ shaped units at interface solution-gas.

The values of the specific surface energies used in the above calculation are founded in Table 1.

Table 1. Chosen nucleation parameters of hydrate.

\begin{tabular}{|c|c|}
\hline Characteristic quantity & value \\
\hline Surface energy solution/gas, $\sigma_{s g}$ & $70 \mathrm{~mJ} . \mathrm{m}^{-2}$ \\
\hline Surface energy hydrate/gas, $\sigma_{\mathrm{hg}}$ & $80 \mathrm{~mJ} . \mathrm{m}^{-2}$ \\
\hline Surface energy solution/hydrate, $\sigma$ & $15 \mathrm{~mJ} . \mathrm{m}^{-2}$ \\
\hline
\end{tabular}

At the stage of the solution and the finishing phase there is an experimental device, shown in Figure 3. The device will serve to create hydrates under laboratory conditions and in the following to compare actual consumption of energy consumed by the device with theoretical values [5-14]. 


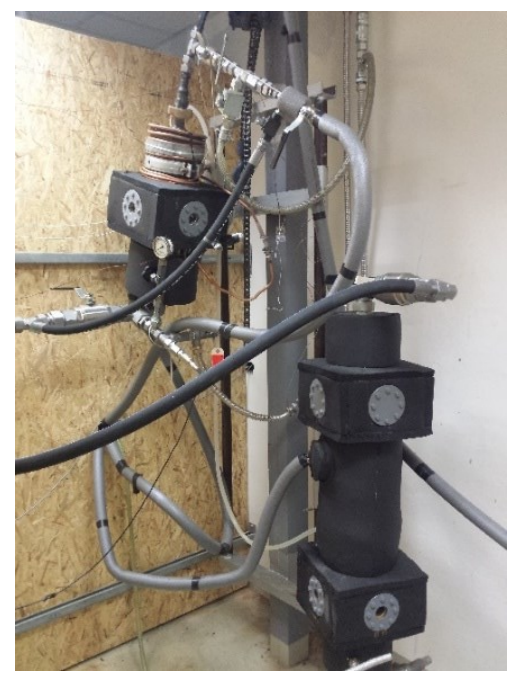

Fig. 3. Experimental device in the finishing process.

\section{Conclusion}

Artificially created hydrates appear to be a prospective means of energy accumulation in the 21 st century. Storage of gas in the form of hydrates is possible at relatively high temperatures and low pressures compared to other gaseous hydrocarbon storage technologies. At the same time, this method of energy storage appears to be advantageous both in terms of storage capacity and security. The article describes a modeling of hydrate formation using selected parameters related to the experimental device that is in the finishing phase.

Work on the article was financially supported by VEGA 1/0738/18. Optimalizácia energetických vstupov pre rýchle generovanie hydrátov zemného plynu a biometánu na akumuláciu vysokopotenciálnej primárnej energie

\section{References}

1. A. Demirbas, $E C M, 51(2010)$

2. V. Foltin, J. Rajzinger, J. Juriga, Š. Gužel'a, In Vykurovanie, SSTP, Bratislava (2013)

3. S. Čičmanec, Perspektívy využívania zemného plynu v SR (2004)

4. S. Depowski, In Kotliński, Szamałek (red.) Surovce minerálne mórz i oceanów (1998)

5. N. Gnanendran, R. Amin, Chemical engineering science 59, 3849-3863 (2004)

6. A. Dimiccoli, M. Di Serio, E. Santacesaria, Ind.\& Eng. Chem. Res. 39 (2000)

7. V. Srinivasan, C.R. Aiken, Chemical Engineering Science 43 (1988)

8. E.G.V. Levich, Physioch. Hydrodynamics, Prentice-Hall, Englewood Cliffs, NJ. (1962)

9. H.A. Lefebvre, Atomization and Sprays, Hemisphere, New York (1989)

10. R. Perry, Perry's chemical engineers' handbook, 7th ed., McGraw-Hill Comp. (1997)

11. D. Kashchiev, A. Firoozabadi, Journal of Crystal Growth, 243 (2002)

12. M. Holubčík, J. Jandačka, Š. Papučík, P. Pilát, Manuf. Technology, 15 (2015)

13. J. Jandačka, et al., Emisné zat’aženie životného prostredia, Edis (2015)

14. P. Durčanský, et al., Scientific World Journal, 2014 (2014) 